\title{
Assessment of drinking water contamination in food stalls of Jashore Municipality, Bangladesh
}

\author{
Molla Rahman Shaibur $^{1}$ D . Mohammed Sadid Hossain ${ }^{1} \cdot$ Shirina Khatun $^{1} \cdot$ F. K. Sayema Tanzia ${ }^{2}$
}

Received: 30 November 2020 / Accepted: 9 July 2021 / Published online: 26 July 2021

(c) The Author(s) 2021

\begin{abstract}
This study aimed to determine the quality of drinking water supplied in different types of food stalls in Jashore Municipality, Bangladesh. A total of 35 water samples were collected from different tea stalls, street side fast food stalls, normal restaurants and well-furnished restaurants. The water quality was evaluated by determining the distinct physical, chemical and biological parameters. The results revealed that the water used in the food stalls and restaurants for drinking purpose was in desired quality in terms of turbidity, electrical conductivity, $\mathrm{pH}$, total dissolved solids, nitrate $\left(\mathrm{NO}_{3}^{-}\right)$, sulfate $\left(\mathrm{SO}_{4}{ }^{2-}\right)$, phosphate $\left(\mathrm{PO}_{4}{ }^{3-}\right)$, chloride $\left(\mathrm{Cl}^{-}\right)$, sodium (Na) and potassium $(\mathrm{K})$ concentrations. The values were within the permissible limit proposed by the Bangladesh Bureau of Statistics and the World Health Organization. Concentrations of calcium (Ca) and magnesium $(\mathrm{Mg}$ ) found in several samples were higher than the World Health Organization standard. Iron (Fe) concentrations were higher than the permissible limit of the World Health Organization. Only 46\% exceeded the permissible limit of Bangladesh Bureau Statistics. The threatening result was that the samples were contaminated by fecal coliform, indicating that the people of Jashore Municipality may have a greater chance of being affected by pathogenic bacteria. The drinking water provided in the street side fast food stalls was biologically contaminated. The findings demonstrate that the drinking water used in food stalls and restaurants of Jashore Municipality did not meet up the potable drinking water quality standards and therefore was detrimental to public health.
\end{abstract}

Keywords BBS $\cdot$ Coliform bacteria $\cdot$ Permissible limit $\cdot$ Tea stalls $\cdot \mathrm{Fe} \cdot \mathrm{WHO}$

$\begin{array}{ll}\text { Abbreviations } \\ \text { BBS } & \text { Bangladesh Bureau of Statistics } \\ \text { DTW } & \text { Deep Tube Well Water, } \\ \text { EC } & \text { Electrical Conductivity, } \\ \text { JUST } & \text { Jashore University of Science and Technology } \\ \text { NR } & \text { Normal Restaurants, } \\ \text { NTU } & \text { Nephelometric Turbidity Unit } \\ \text { PSF } & \text { Pond Sand Filter } \\ \text { TDS } & \text { Total Dissolved Solids } \\ \text { TS } & \text { Tea Stalls } \\ \text { TW } & \text { Tube Well Water }\end{array}$

Molla Rahman Shaibur

shaibur75@yahoo.com; shaibur75@just.edu.bd

1 Laboratory of Environmental Chemistry, Department of Environmental Science and Technology, Jashore University of Science and Technology, Jashore 7408, Bangladesh

2 Department of Environmental Science and Engineering, Jatiya Kabi Kazi Nazrul Islam University, Trishal, Namapara Mymensingh 2220, Bangladesh

$\begin{array}{ll}\text { SSFS } & \text { Street Side Fast Food Stalls } \\ \text { SW } & \text { Supply Water } \\ \text { USEPA } & \text { United States Environmental Protection Agency } \\ \text { WFR } & \text { Well-furnished Restaurants } \\ \text { WHO } & \text { World Health Organization }\end{array}$

\section{Introduction}

Water quality refers to its physical, chemical and biological characteristic (Islam et al. 2017c; Diersing 2009; Adimalla and Taloor 2020). Water quality in Bangladesh is not up to the mark. More specifically, water supply in the restaurants in Bangladesh is not good enough. Drinking water provided in the street food of Dhaka city is mostly unsafe in terms of E. coli, total enteric bacterial count and total bacterial count (Faruque et al. 2010). Many diseases are directly or indirectly related to water quality. Cholera, diarrhea, dysentery and hepatitis-A are linked to unhygienic and contaminated potable water. It is estimated that each year more than 842,000 people die from diarrhea globally (WHO 2017). 
The supply of safe drinking water is crucial to human life (WHO 2011). Although a few heavy metals are essential for human health, an excess amount of these metals can have adverse effects. Heavy metals are released into the environment through a natural process and anthropogenic activities. The sources of drinking water, e.g., surface water (Shaibur et al. 2021a, b) and groundwater are likely to be contaminated or polluted by various factors (Shaibur et al. 2019f; Shaibur et al. 2021b) including heavy metals (Shaibur et al. 2012; Shaibur 2019; Shaibur et al. 2019a, d; Shaibur and Howlader 2020). Several heavy metals can cause lifethreatening diseases like cancer, e.g., inorganic arsenic and non-cancer, e.g., Hg risks in humans (USEPA 2014).

In recent times, the microbial safety of drinking water has become a burning issue and public awareness (Shaibur et al. 2012) is gradually increasing regarding waterborne diseases (da-Silva et al. 2008). Pipe line water quality may be acceptable when the water just leaves the treatment plant. However, a variety of physical, chemical and biological transformations can happen once the water travels through the distribution system (Lahlou 2002). Deterioration in water treatment facilities (Shaibur et al. 2019c) and distribution systems can pose a significant public health threat and diarrheal disease could be attributed to cross-connection between the municipal supply water and sewer due to leaky joints (Semenza et al. 1998). Improper handling and serving practice in hotels, WFR, NR, SSFS and TS cause microbial contamination to the conventional drinking water provided to the consumers (Tambekar et al. 2006). Most of the vendors of SSFS of Dhaka city suffer from dysentery, diarrhea and gastrointestinal diseases (Faruque et al. 2010) though street foods are very tasty and cheaper (Islam et al. 2017b). Nowadays, people are more attracted to street foods and foods served in restaurants.

The current population of Bangladesh is $165,939,921$ as of Wednesday, April 7, 2020, based on Worldometer of the latest United Nations data with an area of $130,170 \mathrm{Km}^{2}$ (50,259 sq. miles; https://www.worldometers.info/worldpopulation/bangladesh-population/). About $39.4 \%$ of the populations are urban, which means the majority of the people live in villages. The economic condition is also not so good. The sanitation condition of Bangladesh is not up to the mark (Shaibur et al. 2019b). The Bangladeshi is not conscious of their dietary pattern and health (Islam et al. 2015). Usually, they use to eat outside home (Khairuzzaman et al. 2014). Especially, they prefer street food, e.g., TS, SSFS (Sekar and Thamilselvi 2016), NR and comparatively WFR. This is highly unfortunate as the food stalls do not maintain the quality of foods served and water supplied for drinking purposes in Bangladesh. Substandard quality of food ingredients and sanitation are integral to enteric pathogen exposure, drinking water is a major source of microbial pathogens in developing world (Ashbolt 2004). Despite of that about $98 \%$ of people having access to water from technologically advanced water sources; the quality of water in Bangladesh is still poor (Islam et al. 2015; Shaibur et al. 2019 e, f). About $41 \%$ of all improved water sources in Bangladesh are contaminated with E. coli despite of remarkable progress in improving access to water supply and sanitation (Shaibur et al. 2019b). E. coli affects the poor and rich and the urban and rural people uniformly (Nabi 2018).

In Bangladesh, eating habit is changing, as people prefer to have food at outside stalls or restaurants. Usually, they eat their food and meals in various roadside restaurants because of taste, low price, accessibility, huge varieties and above all the needs of street people (Islam et al. 2017b). Normally, people drink water provided when they are in restaurants for their breakfast, lunch or dinner. In cases, the water is stored in a large plastic drum or earthen pot (Kola) or plastic tank without lids. Sometimes tube well water or locally supplied water is also provided to the consumers for the same, because groundwater is considered to be free from microbial contamination (Shaibur et al. 2012). The Bangladeshi people usually do not want to pay for drinking water. They usually drink the available dirty water to meet up their sudden thirst. As a result, they usually suffer from diarrhea, dysentery and gastric pain. The people of Jashore Municipality are also not exempted on this said subject matter.

Jashore Municipality is the second largest Municipality next to Khulna in the Khulna Division. There are three big bus stands, and the largest land port of Bangladesh (Benapole port) is situated in Jashore District. Besides these, various types of industries, educational institutions, hotels and restaurants are also present here. Many people from lower to higher class are involved with these institutions, residing here and are using the restaurants or food stalls for consuming foods. In restaurants, stored water or tap water is provided to the consumers. After having food and water many people suffer from various waterborne diseases in this Municipality. Therefore, the objective of this study was to determine the drinking water quality of these stalls and restaurants to evaluate the suitability if the provided water was safe or not for a consumer's health. In this case, we determined some physical, chemical and biological properties of the water supplied to the restaurants.

\section{Materials and methods}

\section{Study area}

The study was conducted in the Jashore Municipality under Jashore District (Fig. 1a,b,c). Jashore District has an area of about 2,578.20 $\mathrm{Km}^{2}$, but the area of Jashore town is 25.72 $\mathrm{Km}^{2}$. The Municipality was established on August 1, 1864 and presently it is stretched over an area of about $14.72 \mathrm{Km}^{2}$. 

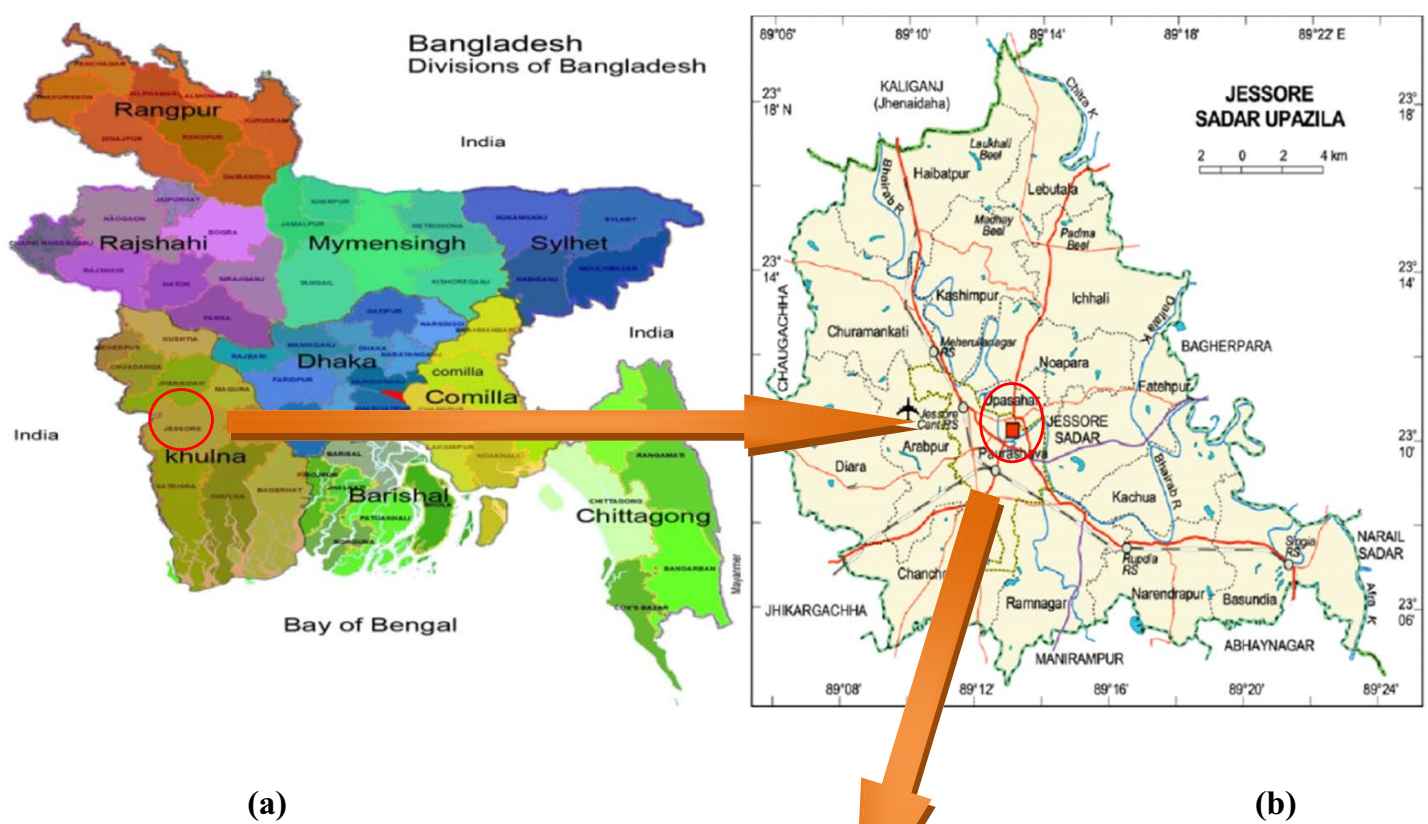

(a)

(b)

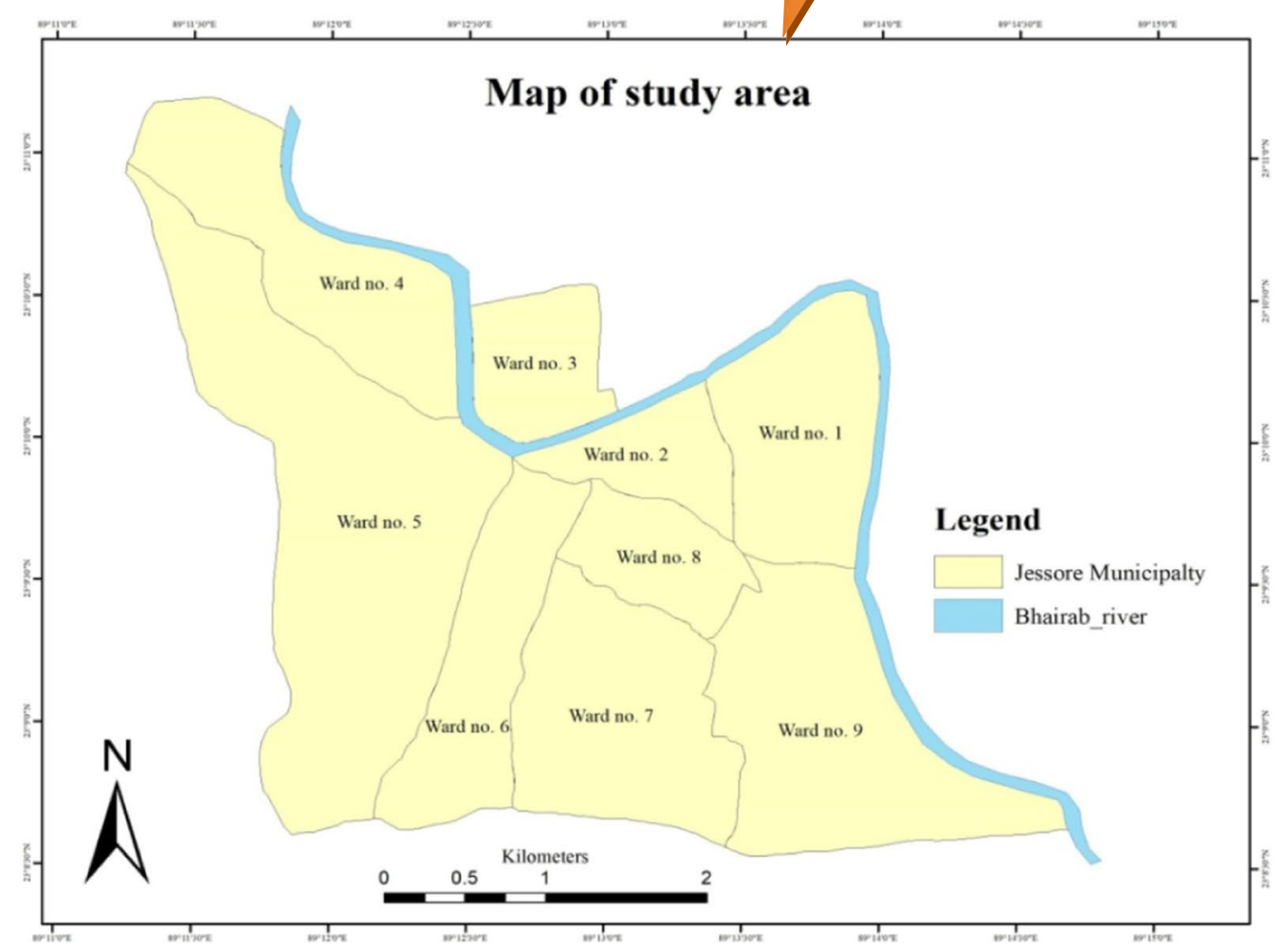

(c)

Fig. 1 Location map of the study area: a Map of Bangladesh, b Map of Jashore Sadar Upazila \& c Map of the Jashore Municipality. These photographs were collected from net 
It is one of the oldest and 13th biggest Municipalities in

Bangladesh with 9 wards (Shaibur et al. 2012, 2019b).

\section{Sampling site and sample collection}

Samples were collected from 35 selected food stalls including 9 TS, 9 SSFS, 9 NR and 8 WFR. The detailed information of the sampling points is summarized in Table 1 with GPS coordination (Magellan eXplorist 310). The samples were collected from May 2018 to July 2018 during the summer.

\section{Description of the food stalls}

Different types of food stalls, e.g., TS, SSFS, NR and WFR are present in the Jashore Municipality. These food stalls provide locally SW, TW, DTW or stored water to their consumers. Some vendors use their mini motor to collect the drinking water.

Tea Stalls These are the TS usually found on the road side. Usually, they store water in the earthen pot or plastic tank with or without a lid. Often, the environmental conditions were very dirty in or around the TS.
Table 1 Samples location with global positioning system (GPS) condemnation of the different usual food stalls in 9 wards of Jashore Municipality

\begin{tabular}{|c|c|c|c|c|c|}
\hline \multirow[t]{2}{*}{ Ward No } & \multirow[t]{2}{*}{ Sample ID } & \multirow[t]{2}{*}{ Water Source } & \multirow[t]{2}{*}{ Area } & \multicolumn{2}{|l|}{ GPS Reading } \\
\hline & & & & Latitude (N) & Longitude (E) \\
\hline \multirow[t]{4}{*}{01} & TS 1 & TW & Purba Barandipara & $2310^{\prime} 00^{\prime \prime}$ & $8913^{\prime} 14^{\prime \prime}$ \\
\hline & SSFS 1 & TW & & & \\
\hline & NR 1 & SW & City College Para & $2309^{\prime} 36^{\prime \prime}$ & $8913^{\prime} 20^{\prime \prime}$ \\
\hline & WFR 1 & SW & & & \\
\hline \multirow[t]{3}{*}{02} & TS 2 & DTW & Kapuria Patti & $2310^{\prime} 00^{\prime \prime}$ & $8912^{\prime} 47^{\prime \prime}$ \\
\hline & SSFS 2 & DTW & & & \\
\hline & NR 2 & DTW & & & \\
\hline \multirow[t]{4}{*}{03} & TS 3 & TW & Newmarket & $2310^{\prime} 31 "$ & 89 12' 51" \\
\hline & SSFS 3 & TW & & & \\
\hline & NR 3 & TW & & & \\
\hline & WFR 3 & TW & & & \\
\hline \multirow[t]{4}{*}{04} & TS 4 & $\mathrm{TW}$ & Palbari & $2310^{\prime} 40^{\prime \prime}$ & 89 11'35" \\
\hline & SSFS 4 & $\mathrm{TW}$ & & & \\
\hline & NR 4 & TW & & & \\
\hline & WFR 4 & TW & & & \\
\hline \multirow[t]{4}{*}{05} & TS 5 & TW & Arabpur & $2310^{\prime} 08^{\prime \prime}$ & 89 12'33" \\
\hline & NR 5 & $\mathrm{TW}$ & & & \\
\hline & SSFS 5 & TW & Doratana Mor & $2310^{\prime} 01 "$ & 89 12'34" \\
\hline & WFR 5 & TW & & & \\
\hline \multirow[t]{4}{*}{06} & TS 6 & TW & Chachra & $2308^{\prime} 35^{\prime \prime}$ & $8911^{\prime} 50 "$ \\
\hline & SSFS 6 & $\mathrm{TW}$ & & & \\
\hline & NR 6 & TW & & & \\
\hline & WFR 6 & $\mathrm{TW}$ & & & \\
\hline \multirow[t]{4}{*}{07} & TS 7 & TW & Sankarpur & $2308^{\prime} 58^{\prime \prime}$ & 89 12'46.9" \\
\hline & SSFS 7 & TW & & & \\
\hline & NR 7 & TW & & & \\
\hline & WFR 7 & $\mathrm{TW}$ & & & \\
\hline \multirow[t]{4}{*}{08} & TS 8 & $\mathrm{TW}$ & Bejpara & $2310^{\prime} 01 "$ & $8912^{\prime} 51^{\prime \prime}$ \\
\hline & SSFS 8 & TW & & & \\
\hline & NR 8 & $\mathrm{TW}$ & & & \\
\hline & WFR 8 & TW & & & \\
\hline \multirow[t]{4}{*}{09} & TS 9 & TW & Bogchar & $2310^{\prime} 11 "$ & 89 13' 51" \\
\hline & SSFS 9 & $\mathrm{TW}$ & & & \\
\hline & NR 9 & TW & & & \\
\hline & WFR 9 & TW & & & \\
\hline
\end{tabular}

N.B.: $D T W$ Deep Tube Well Water, NR Normal Restaurants, TS Tea Stalls, $T W$ Tube Well Water, SSFS Street Side Fast Food Stalls, SW Supply Water, WFR Well-furnished Restaurants 
Street Side Fast food Stalls These stalls are moving stalls. Usually, they serve food on a mobile van. Few cheap delicious foods, e.g., fuchka and chotpoti are sold here. The vendors keep the drinking water in plastic or earthen container.

Normal Restaurants The number of this type of stall is considerably large. It is generally a fixed type stall. Generally, bread (ruti), fried bread (parata), singara, puri and sweet items are sold there. The environmental conditions are comparatively better than TS and SSFS but worse than the WFR.

Well-furnished Restaurants The numbers of WFR are not so large. The environmental condition is the best considering the other types mentioned. Usually, it has some sitting arrangement, e.g., chair, table and bench and the utensils are the best among the four.

\section{Statistical analysis}

Before undertaking the research, a reconnaissance survey was conducted. At every point, 3 samples were collected and the average of the three was made. The standard deviation was calculated. Data were analyzed by using a Ryan-Einot-Gabriel-Welsch multiple range tests $(\mathrm{P}=0.05$; SAS1988). The water quality parameters of the samples were compared with standard values prescribed by WHO and BBS drinking water guidelines.

\section{Methods used for analysis}

Physicochemical Parameter: Turbidity was measured by using a digital Spectrophotometer HACH; 2100Q. The EC was measured by using EC/TDS/Temperature testerHANNA; Model HI 98,312; S: 349,459; Waterproof IP57: Mauritius (Eaton et al. 2005). The $\mathrm{pH}$ was determined by a membrane electrode method using $\mathrm{pH}$ meter- Ezodo-6011; S/N: 000,367; Waterproof IP57: Taiwan (Eaton et al. 2005). The TDS was determined by using EC/TDS/Temperature tester- HANNA; Model HI 98,312; S: 349,459; Waterproof IP57: Mauritius (Eaton et al. 2005). Nitrate $\left(\mathrm{NO}_{3}{ }^{-}\right)$, sulfate $\left(\mathrm{SO}_{4}{ }^{2-}\right)$ and phosphate $\left(\mathrm{PO}_{4}{ }^{3-}\right)$ were analyzed by powder pillow procedure using Spectrophotometer HACH; DR 3900 (Huang and Fujii 2001). Chloride $\left(\mathrm{Cl}^{-}\right)$was analyzed by Mohr's procedure (Eaton et al. 2005). Sodium and K were characterized by using Flame Photo Meter JENWAY- Model PFP7/C while $\mathrm{Ca}$ and $\mathrm{Mg}$ were by using EDTA methods (Eaton et al. 2005). Iron was measured by powder pillow procedure using Spectrophotometer HACH; DR 3900 (Huang and Fujii 2001). The detailed methodology was described earlier in the literature (Shaibur et al. 2012, 2017 , 2018; Shaibur et al. 2019a, d, e, f).
Determination of Biological Parameters: Total coliform (TC) and fecal coliform (FC) were analyzed by membrane filtration methods using Cooled Incubator; FOC-120E and Incubator; JSGI-30 T (Eaton et al. 2005; Shaibur et al. 2012).

\section{Results and discussion}

\section{Physicochemical parameters}

\section{Turbidity}

The range of turbidity in the collected water samples of different food stalls was from 0.17 to 3.84 NTU (Fig. 2a). The highest value of turbidity was 3.84 NTU in Doratana Mor (WFR 5), and the lowest was 0.17 NTU in Palbari (NR 4; Fig. 2a). The permissible limit in drinking water is 10.0
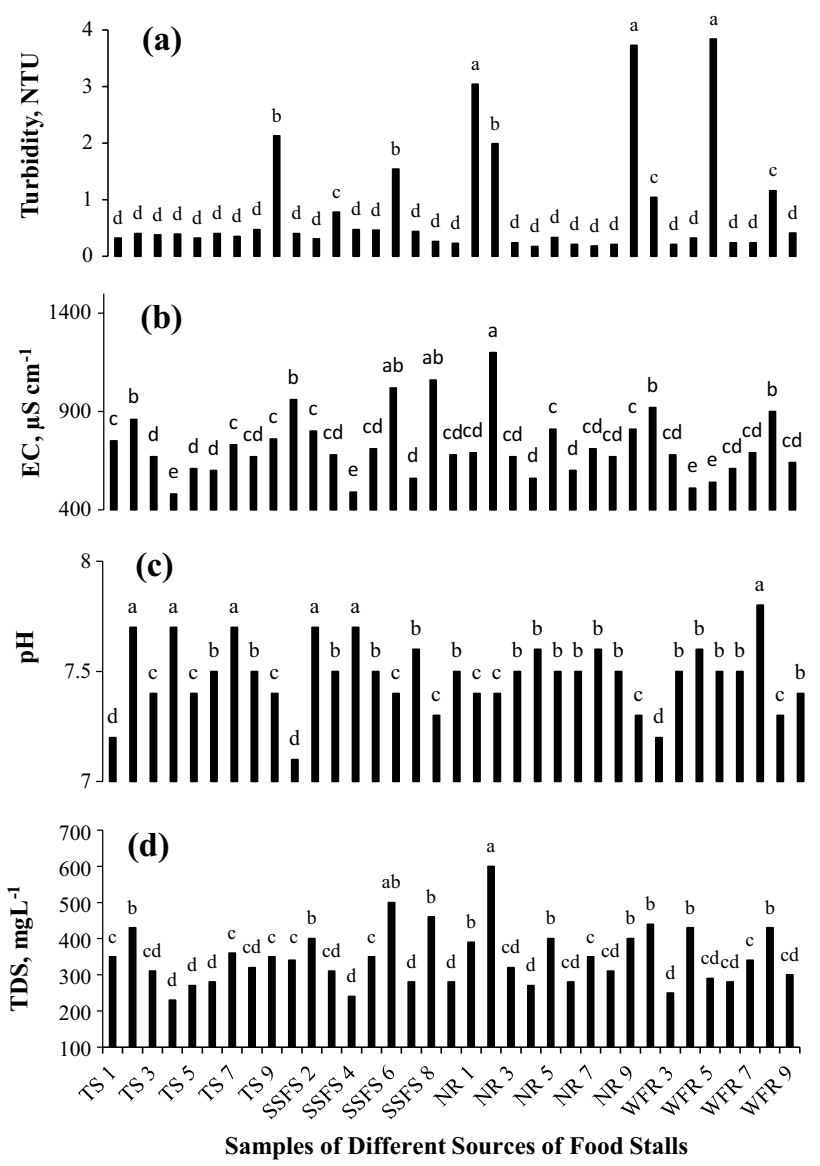

Fig. 2 Some parameters determined in water samples. a Turbidity, b $\mathrm{EC}=$ Electrical Conductivity, $\mathbf{c} \mathrm{pH}$ and $\mathbf{d}$ TDS $=$ Total Dissolved Solids at different sources of food stalls. NR $=$ Normal Restaurants, $\mathrm{TS}=$ Tea Stalls, SSFS $=$ Street Side Fast Food Stalls and WFR $=$ Wellfurnished Restaurants. Bars with different letters are significantly different $(p<0.05)$ according to a Ryan-Einot-Gabriel-Welsch multiple range test

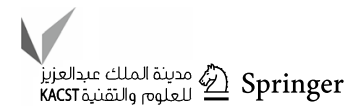


NTU (BBS 2009) and 5.0 NTU (WHO 1984), indicating that the turbidity concentrations of the collected water samples were within the permissible limit. Water becomes turbid due to the presence of suspended materials. High turbidity is caused by particulate matter in the water that either is not filtrated adequately from the source or comes from resuspended sediment in the distribution system (WHO 2004). The water was good for drinking purposes considering the turbidity. This is the basic data but it contained the information of the study area. Till date, the turbidity of drinking water used in different food stalls of Jashore or Bangladesh is not available. Turbidity of DTW (Shaibur et al. 2012), HTW (Shaibur et al. 2019a, d) and HTW and DTW water (Shaibur et al. 2019a) of JUST campus were good enough. However, the turbidity of pond water, DTW or even PSF water exceeded the standard values of Bangladesh and WHO (Shaibur et al. 2019f). Similarly, the turbidity of the water of Nolamara beel was very high compared to standard value (Shaibur et al. 2017). These differences were most probably due to the differences of sources of water and the geographical position of the water sources.

\section{Electrical conductivity (EC)}

The range of EC value was from 480.0 to $1200.0 \mu \mathrm{S} \mathrm{cm}^{-1}$ (Fig. 2b). The maximum value was $1200.0 \mu \mathrm{S} \mathrm{cm}^{-1}$ in NR at Kapuria Patti (NR 2) and the minimum was $480.0 \mu \mathrm{S}$ $\mathrm{cm}^{-1}$ in TS at Palbari (TS 4). The EC value of drinking water prescribed by BBS is 300.0 to $1500.0 \mu \mathrm{S} \mathrm{cm}^{-1}$ (BBS 2009). Considering the BBS standard value, all the samples were safe for drinking purposes. The WHO prescribed value of EC was $750.0 \mu \mathrm{S} \mathrm{cm}^{-1}$ (WHO 1984). If we consider the WHO prescribed value, 13 out of 35 samples exceeded the standard limit. Some of them just crossed the boundary limit $750.0 \mu \mathrm{S} \mathrm{cm}^{-1}$. Considering all the facts, the EC of the collected samples was good. But we should be cautious if the EC exceeds the value of $300.0 \mu \mathrm{S} \mathrm{cm}^{-1}$, because of drinking water EC is an indirect measure of the total salt content or TDS. The higher is the salt content, the better is the conduction of current (Shaibur et al. 2012). The higher $\mathrm{EC}$ of the samples may reflect the higher mineralization in the study area. Reports show that EC varied from 55.0 to $353.0 \mu \mathrm{S} \mathrm{cm} \mathrm{cm}^{-1}$ with an average of $120.64 \mu \mathrm{S} \mathrm{cm} \mathrm{cm}^{-1}$ in the groundwater of Dhaka city (Badrud-Doza et al. 2020) and varied from 13.3 to $505.0 \mu \mathrm{S} \mathrm{cm}{ }^{-1}$ in the underground water of Bafia (Cameroon; Nyam et al. 2020). The mean EC of tube well water samples in Khulna city was reported to be $1,650.0 \mu \mathrm{S} \mathrm{cm}^{-1}$ (pre-monsoon; Mahmud et al. 2020). Extremely low EC value $\left(70.0\right.$ to $\left.80.0 \mu \mathrm{S} \mathrm{cm}^{-1}\right)$ in the underground water near a landfill area of Mongla Bazar in Sylhet was also reported (Alam et al. 2020). The variation of EC was most probably due to the variation of the depth of the water sources and may also for the variation of the geographical positions of the water sources. The depth of the water sources of Dhaka city varied from 57.91 to $320.04 \mathrm{~m}$ (Badrud-Doza et al. 2020). Most of the water supplied to the customers of hotels or restaurants was stored from the municipal tap water, supplied by water and sewerage authority (Faruque et al. 2010).

\section{The hydrogen ion concentration $(\mathrm{pH})$}

The BBS and WHO recommended standard value of $\mathrm{pH}$ in drinking water is 6.50 to 8.50 (BBS 2009; WHO 1984). The $\mathrm{pH}$ value in the water samples ranged from 7.10 to 7.80 (Fig. 2c). The maximum value of $\mathrm{pH}$ was 7.80 in WFR at Sankarpur (WFR 7) and the minimum value was 7.10 in SSFS at Purba Barandi Para (SSFS 1; Fig. 2c), indicating that the $\mathrm{pH}$ of all the collected samples was within the permissible limit of BBS and WHO. A recent study portrayed that the $\mathrm{pH}$ of the drinking water in Jashore District varied from 6.40 to 7.80 (Sardar et al. 2017), in JUST campus the values ranged from 7.23 to 7.38 with the mean value of 7.26 (Shaibur et al. 2019a), in suburban areas of Jashore Municipality the value ranged from 6.50 to 7.25 (Shaibur et al. 2019d), in Dhaka city the values were 6.66 to 8.19 with an average of 7.32 (Bodrud-Doza et al. 2020) and in Rajshahi city the $\mathrm{pH}$ was little acidic to neutral (Mostafa et al. 2017). These differences were most probably due to the geographical positions of the sampling points. Jashore is very near to the coastal zone and Dhaka is far from the coastal zone. The $\mathrm{pH}$ of the restaurants of Sylhet city varied from 6.09 to 6.13 (Alam et al. 2006) and the underground water near a landfill area of Mongla Bazar of Sylhet was 6.73 to 7.12 (Alam et al. 2020). The average $\mathrm{pH}$ of tube well (10 to $45 \mathrm{~m}$ ) water samples in Khulna city was 7.30 (Mahmud et al. 2020). A low $\mathrm{pH}$ value in the underground water (4.0 to 6.4) was also reported from Nigeria (Egbueri 2020). The $\mathrm{pH}$ of the water of restaurants largely depends on the $\mathrm{pH}$ of the source water.

\section{Total dissolved solids (TDS)}

The concentrations of TDS in the collected water samples ranged from 230.0 to $600.0 \mathrm{mg} \mathrm{L}^{-1}$ (Fig. 2d). The maximum value of TDS was $600.0 \mathrm{mg} \mathrm{L}^{-1}$ in NR at Kapuria Patti (NR 2) and the minimum value was $230.0 \mathrm{mg} \mathrm{L}^{-1}$ in TS at Palbari (TS 4). The standard limit value of TDS in drinking water is $1,000.0 \mathrm{mg} \mathrm{L}^{-1}$ (BBS 2009; WHO 1984). It was found that all the TDS values of the samples were lower or within the permissible limit of drinking water quality guidelines. The range of TDS in hand tube wells of Jashore Municipality varied from 325.0 to $498.0 \mathrm{mg} \mathrm{L}^{-1}$ (Shaibur et al. 2012) and it varied from 260.0 to $340.0 \mathrm{mg} \mathrm{L}^{-1}$ with the mean value of $304.29 \mathrm{mg}^{-1}$ in JUST campus (Shaibur et al. 2019a). Similarly, the value varied from 210.0 to $500.0 \mathrm{mg} \mathrm{L}^{-1}$ in the surrounding areas of JUST campus (Shaibur et al. 2019a) and the values were from 
32.9 to $211.0 \mathrm{mg} \mathrm{L}^{-1}$ with an average of 72.22 in Dhaka city (Bodrud-Doza et al. 2020). On the contrary, the mean value of TDS in tube wells in Khulna city was $1,188.7 \mathrm{mg} \mathrm{L}^{-1}$ (Mahmud et al. 2020). Another report showed that the TDS varied from 237.0 to $3,112 \mathrm{mg} \mathrm{L}^{-1}$ with an average of $1,556.05 \mathrm{mg}$ $\mathrm{L}^{-1}$ in tube wells water (21.0 to $54.0 \mathrm{~m}$; Islam et al. $2017 \mathrm{c}$ ). These differences were most probably due to the variation of the depth of water sources and the geographical position of the sampled areas. Khulna city is near the coastal region, but Jashore and Dhaka are far from the coastal region.

\section{Nitrate $\left(\mathrm{NO}_{3}{ }^{-}\right)$, sulfate $\left(\mathrm{SO}_{4}{ }^{2-}\right)$, phosphate $\left(\mathrm{PO}_{4}{ }^{3-}\right)$ and chloride $\left(\mathrm{Cl}^{-}\right)$.}

The $\mathrm{NO}_{3}{ }^{-}$concentrations in food stalls water varied from 0.55 to $0.90 \mathrm{mg} \mathrm{L}^{-1}$ which were within the limit of drinking water (Table 2). The BBS standard value of $\mathrm{NO}_{3}{ }^{-}$in drinking water is $10.0 \mathrm{mg} \mathrm{L}^{-1}$ (BBS 2009), but the value is $50.0 \mathrm{mg} \mathrm{L}^{-1}$ for WHO (WHO 1984). Considering both the limits our collected samples were safe for drinking purpose. Nitrate concentrations varied from 0.37 to $31.1 \mathrm{mg} \mathrm{L}^{-1}$ in pre-monsoon of the groundwater of Gopalganj District, and the values were 0.08 to $32.5 \mathrm{mg} \mathrm{L}^{-1}$ in post-monsoon for the same (Rahman et al. 2017). A wide range of $\mathrm{NO}_{3}{ }^{-}$concentrations ( 0.0 to $4.0 \mathrm{mg} \mathrm{L}^{-1}$ ) were found in the underground water (Nyam et al. 2020). The $\mathrm{NO}_{3}{ }^{-}$concentration in the groundwater of JUST campus varied from 2.0 to $4.0 \mathrm{mg}$ $\mathrm{L}^{-1}$ and the values were from 2.0 to $9.0 \mathrm{mg} \mathrm{L}^{-1}$ in the surrounding areas of the campus (Shaibur et al. 2019a). The suggested variations were mostly due to variation of depth, variation of water sources and time of sample collections and were the geographical positions of water samples.

The range of $\mathrm{SO}_{4}{ }^{2-}$ concentrations of the collected drinking water varied from 2.0 to $4.0 \mathrm{mg} \mathrm{L}^{-1}$ (Table 2), whereas the BBS standard value of $\mathrm{SO}_{4}{ }^{2-}$ is $400.0 \mathrm{mg} \mathrm{L}^{-1}$ (BBS 2009) and the WHO standard value is $250.0 \mathrm{mg} \mathrm{L}^{-1}$ (WHO 1984). This indicates that the values of the samples were within the standard value of drinking water. In Bangladesh, both surface and groundwater sources contained an insignificant amount of $\mathrm{SO}_{4}{ }^{2-}$ (Sultana et al. 2009) which is strongly supported by our result. A very low concentration of $\mathrm{SO}_{4}{ }^{2-}$ (from 1.0 to $4.0 \mathrm{mg} \mathrm{L}^{-1}$ ) in hand tube well water is also reported from suburban areas of Jashore Municipality (Shaibur et al. 2019d). In monsoon, the $\mathrm{SO}_{4}{ }^{2-}$ concentration varied from 1.63 to $105.09 \mathrm{mg} \mathrm{L}^{-1}$ with the mean value of $14.74 \mathrm{mg} \mathrm{L}^{-1}$ in Satkhira Municipality, but in dry season, the values varied from 0.01 to $3.53 \mathrm{mg} \mathrm{L}^{-1}$ with the mean value of $0.64 \mathrm{mg} \mathrm{L}^{-1}$ (Das et al. 2021a). A sulfate concentration in underground water of Ojoto suburban areas in Southeast Nigeria varies from 8.0 to $130.0 \mathrm{mg} \mathrm{L}^{-1}$ (Egbueri 2020).

The $\mathrm{PO}_{4}{ }^{3-}$ concentration in the collected water samples varied from 0.40 to $0.74 \mathrm{mg} \mathrm{L}^{-1}$ (Table 2). The BBS set $6.0 \mathrm{mg} \mathrm{L}^{-1}$ as the permissible limit of $\mathrm{PO}_{4}{ }^{3-}$ (BBS 2009).
The result suggested that all the water samples contained a suitable concentration of phosphorus. Low concentrations of $\mathrm{PO}_{4}{ }^{3-}\left(0.21\right.$ to $\left.0.85 \mathrm{mg} \mathrm{L}^{-1}\right)$ in the hand tube well water were also reported from suburban regions of Jashore Municipality (Shaibur et al. 2019d). Concentrations of $\mathrm{PO}_{4}{ }^{3-}$ in the groundwater of Gopalganj District varied from 0.16 to $2.82 \mathrm{mg} \mathrm{L}^{-1}$ in pre-monsoon and from 0.20 to $5.74 \mathrm{mg} \mathrm{L}^{-1}$ in post-monsoon (Rahman et al. 2017). A low concentration of $\mathrm{PO}_{4}{ }^{3-}$ (0.02 to $\left.1.78 \mathrm{mg} \mathrm{L}^{-1}\right)$ in groundwater was also reported (Nyam et al. 2020). In dry season (December), the $\mathrm{PO}_{4}{ }^{3-}$ concentration varied from 0.006 to $3.69 \mathrm{mg} \mathrm{L}^{-1}$ with the mean value of $0.61 \mathrm{mg} \mathrm{L}^{-1}$ in Koyra Upazila, Khulna, Bangladesh (Das et al. 2021b).

The $\mathrm{Cl}^{-}$concentrations of our collected samples varied from 14.18 to $37.22 \mathrm{mg} \mathrm{L}^{-1}$ (Table 2). The BBS permissible limit of $\mathrm{Cl}^{-}$concentration is 150.0 to $200.0 \mathrm{mg} \mathrm{L}^{-1}$ (BBS 2009), and the WHO limit value is $250.0 \mathrm{mg} \mathrm{L}^{-1}$ (WHO 1984). Our result manifested that the $\mathrm{Cl}^{-}$concentrations in our samples were within the permissible limit. Generally, DTW and hand tube well water of Jashore region contain normal concentration of $\mathrm{Cl}^{-}$(Shaibur et al. 2012). Chlorine concentrations in groundwater of Ojoto suburban areas in Southeast Nigeria varied from 2.0 to $33.0 \mathrm{mg} \mathrm{L}^{-1}$ (Egbueri 2020). In the saline-prone area, the groundwater of shallow tube well contained as high as $14,517 \mathrm{mg} \mathrm{L}^{-1} \mathrm{Cl}^{-}$(Islam et al. 2017a). Chloride is a naturally occurring anion, which can be found in every water source and it is a relatively minor contaminant (Kelly et al. 2012).

\section{Sodium $(\mathrm{Na})$, potassium $(\mathrm{K})$, calcium $(\mathrm{Ca})$ and magnesium (Mg)}

Sodium concentrations in drinking water of different food stalls and restaurants varied from 12.0 to $25.0 \mathrm{mg} \mathrm{L}^{-1}$ (Table 2). The BBS and WHO permissible limit of Na concentration in drinking water is $200.0 \mathrm{mg} \mathrm{L}^{-1}$ (Table 2). Considering the recommended values, the samples contained very little concentrations of $\mathrm{Na}$, and therefore, the water was considered to be safe. Sodium concentrations in supplied water samples of restaurants in Sylhet city were low (Alam et al. 2006). This finding is in line with low concentrations of $\mathrm{Na}\left(0.07\right.$ to $2.84 \mathrm{mg} \mathrm{L}^{-1}$ ) in groundwater (Nyam et al. 2020). On the contrary, the shallow tube well water of coastal District Barguna contains fairly high concentration $(863.0 \mathrm{mg}$ $\mathrm{L}^{-1}$ ) of $\mathrm{Na}$ (Islam et al. 2017a). Sodium is frequently present in drinking water and mostly found as $\mathrm{NaHCO}_{3}$ and $\mathrm{Na}_{2} \mathrm{SO}_{4}$ (Whelton et al. 2007).

Potassium concentrations in the collected water samples varied from 2.0 to $7.0 \mathrm{mg} \mathrm{L}^{-1}$ (Table 2). The prescribed standard values are $12.0 \mathrm{mg} \mathrm{L}^{-1}$ (BBS 2009) and $30.0 \mathrm{mg}$ $\mathrm{L}^{-1}$ (WHO 1984; Table 2), indicating that $\mathrm{K}$ concentrations of all the food stalls and restaurants were lower than the BBS and WHO standard. The supplied water used for 
Table 2 Comparison of some chemical parameters with WHO \& Bangladesh standards for drinking water of different food stalls \& restaurants of Jashore Municipality

\begin{tabular}{|c|c|c|c|c|c|c|c|c|c|c|}
\hline \multicolumn{2}{|l|}{ Parameters } & \multirow{2}{*}{$\begin{array}{l}\mathrm{NO}_{3}^{-} \\
\left(\mathrm{mg} \mathrm{L}^{-}\right.\end{array}$} & \multirow{2}{*}{$\begin{array}{l}\mathrm{SO}_{4}^{2-} \\
-1)\end{array}$} & \multirow{2}{*}{$\mathrm{PO}_{4}{ }^{2-}$} & \multirow[t]{2}{*}{$\mathrm{Cl}^{-}$} & \multirow[t]{2}{*}{$\mathrm{Na}$} & \multirow[t]{2}{*}{$\mathrm{K}$} & \multirow[t]{2}{*}{$\mathrm{Ca}$} & \multirow[t]{2}{*}{$\mathrm{Mg}$} & \multirow[t]{2}{*}{$\mathrm{Fe}$} \\
\hline Ward No & Sample ID & & & & & & & & & \\
\hline BBS2009 & & 10.0 & 400.0 & 6.00 & $150-600$ & 200.0 & 12.0 & 75.0 & $30.0-35.0$ & $0.30-1.0$ \\
\hline WHO 1984 & & 50.0 & 250.0 & - & 250.0 & 200.0 & 30.0 & 100.0 & 150.0 & 0.30 \\
\hline 01 & TS 1 & 0.70 & 2.00 & 0.51 & 26.59 & 20.0 & 2.00 & 64.13 & 48.61 & 1.10 \\
\hline 02 & TS 2 & 0.65 & 2.50 & 0.54 & 23.04 & 25.0 & 3.00 & 80.16 & 36.46 & 0.89 \\
\hline 03 & TS 3 & 0.59 & 2.10 & 0.60 & 31.91 & 18.0 & 2.00 & 64.13 & 41.32 & 1.22 \\
\hline 04 & TS 4 & 0.61 & 3.00 & 0.74 & 21.27 & 21.0 & 2.00 & 48.10 & 31.60 & 1.17 \\
\hline 05 & TS 5 & 0.69 & 2.80 & 0.43 & 17.73 & 15.0 & 2.00 & 32.06 & 34.03 & 0.78 \\
\hline 06 & TS 6 & 0.72 & 3.20 & 0.55 & 33.68 & 13.0 & 4.00 & 48.10 & 19.45 & 1.12 \\
\hline 07 & TS 7 & 0.55 & 4.00 & 0.52 & 14.18 & 16.0 & 3.00 & 64.13 & 43.75 & 0.68 \\
\hline 08 & TS 8 & 0.68 & 3.00 & 0.40 & 19.50 & 19.0 & 2.00 & 48.10 & 43.75 & 0.64 \\
\hline 09 & TS 9 & 0.75 & 2.50 & 0.63 & 35.45 & 17.0 & 4.00 & 64.13 & 36.46 & 1.13 \\
\hline 01 & SSFS 1 & 0.67 & 3.0 & 0.52 & 24.82 & 14.0 & 3.00 & 32.06 & 34.03 & 1.14 \\
\hline 02 & SSFS 2 & 0.61 & 3.50 & 0.49 & 21.27 & 21.0 & 5.00 & 64.13 & 48.61 & 0.96 \\
\hline 03 & SSFS 3 & 0.57 & 2.00 & 0.61 & 26.59 & 17.0 & 3.00 & 64.13 & 38.89 & 1.31 \\
\hline 04 & SSFS 4 & 0.81 & 3.10 & 0.65 & 15.95 & 20.0 & 2.00 & 32.06 & 36.46 & 1.02 \\
\hline 05 & SSFS 5 & 0.72 & 3.00 & 0.53 & 35.45 & 15.0 & 4.00 & 48.10 & 41.32 & 0.96 \\
\hline 06 & SSFS 6 & 0.67 & 2.60 & 0.59 & 23.04 & 14.0 & 2.00 & 32.06 & 48.61 & 0.54 \\
\hline 07 & SSFS 7 & 0.65 & 3.00 & 0.62 & 21.27 & 16.0 & 2.00 & 32.06 & 36.46 & 1.20 \\
\hline 08 & SSFS 8 & 0.71 & 3.30 & 0.48 & 31.91 & 18.0 & 3.00 & 96.19 & 48.61 & 0.72 \\
\hline 09 & SSFS 9 & 0.84 & 3.60 & 0.57 & 28.36 & 19.0 & 5.00 & 48.10 & 43.75 & 0.93 \\
\hline 01 & NR 1 & 0.79 & 2.50 & 0.58 & 37.22 & 13.0 & 3.00 & 64.13 & 48.61 & 1.21 \\
\hline 02 & NR 2 & 0.66 & 2.80 & 0.50 & 30.13 & 16.0 & 2.00 & 48.10 & 48.61 & 0.99 \\
\hline 03 & NR 3 & 0.58 & 2.00 & 0.62 & 17.73 & 14.0 & 2.00 & 32.06 & 41.32 & 1.11 \\
\hline 04 & NR 4 & 0.76 & 3.20 & 0.71 & 21.27 & 13.0 & 4.00 & 64.13 & 36.46 & 0.73 \\
\hline 05 & NR 5 & 0.89 & 3.00 & 0.52 & 28.36 & 20.0 & 3.00 & 64.13 & 41.32 & 0.97 \\
\hline 06 & NR 6 & 0.69 & 2.80 & 0.52 & 19.50 & 12.0 & 2.00 & 64.13 & 31.60 & 1.42 \\
\hline 07 & NR-7 & 0.78 & 3.50 & 0.65 & 15.95 & 18.0 & 5.00 & 32.06 & 36.46 & 0.77 \\
\hline 08 & NR 8 & 0.77 & 3.10 & 0.49 & 17.73 & 15.0 & 3.00 & 64.13 & 41.32 & 0.89 \\
\hline 09 & NR 9 & 0.73 & 2.20 & 0.58 & 26.59 & 19.0 & 2.00 & 80.16 & 46.18 & 1.05 \\
\hline 01 & WFR 1 & 0.71 & 2.50 & 0.56 & 31.91 & 14.0 & 7.00 & 80.16 & 51.04 & 0.92 \\
\hline 03 & WFR 3 & 0.63 & 3.40 & 0.61 & 28.36 & 15.0 & 3.00 & 64.13 & 36.46 & 1.03 \\
\hline 04 & WFR 4 & 0.84 & 2.90 & 0.51 & 30.13 & 13.0 & 2.00 & 48.10 & 36.46 & 0.46 \\
\hline 05 & WFR 5 & 0.76 & 3.00 & 0.56 & 21.27 & 18.0 & 5.00 & 64.13 & 46.18 & 0.97 \\
\hline 06 & WFR 6 & 0.80 & 3.70 & 0.46 & 24.82 & 17.0 & 4.00 & 32.06 & 34.03 & 1.36 \\
\hline 07 & WFR 7 & 0.71 & 3.90 & 0.69 & 23.04 & 16.0 & 2.00 & 32.06 & 36.46 & 0.81 \\
\hline 08 & WFR 8 & 0.82 & 2.60 & 0.53 & 28.36 & 14.0 & 2.00 & 48.10 & 46.18 & 0.76 \\
\hline 09 & WFR 9 & 0.90 & 3.00 & 0.72 & 33.68 & 18.0 & 3.00 & 48.10 & 34.03 & 1.14 \\
\hline \multicolumn{11}{|c|}{ Descriptive statistics } \\
\hline Maximum & & 0.90 & 4.00 & 0.74 & 37.22 & 25.0 & 7.00 & 96.19 & 51.04 & 1.42 \\
\hline Minimum & & 0.55 & 2.00 & 0.40 & 14.18 & 12.0 & 2.00 & 32.06 & 19.45 & 0.46 \\
\hline SD & & 0.09 & 0.52 & 0.08 & 6.29 & 2a.92 & 1.24 & 16.99 & 6.76 & 0.23 \\
\hline
\end{tabular}

N.B.: NR Normal Restaurants, SD Standard Deviation, SSFS Street Side Fast Food Stalls, TS Tea Stalls, WFR Well-furnished Restaurants drinking purpose in the restaurants of Sylhet contained low concentration of K (Alam et al. 2006). An extremely low concentration of $\mathrm{K}\left(0.021\right.$ to $\left.0.83 \mathrm{mg} \mathrm{L}^{-1}\right)$ in groundwater was also found (Nyam et al. 2020). It is also reported that shallow tube well water in the groundwater of South
Central Coastal region of Bangladesh represented the higher concentration of K (Islam et al. 2017a; Hasan et al. 2019). The concentration of $K$ found in water samples is less than any other major cations and it is mostly present in water as $\mathrm{KHCO}_{3}, \mathrm{~K}_{2} \mathrm{SO}_{4}$ and $\mathrm{KCl}$ (Whelton et al. 2007). 
Calcium concentration varied from 32.06 to $96.19 \mathrm{mg}$ $\mathrm{L}^{-1}$ (Table 2). The BBS recommended limit value of $\mathrm{Ca}$ in drinking water is $75.0 \mathrm{mg} \mathrm{L}^{-1}$, and the WHO limit value is $100.0 \mathrm{mg} \mathrm{L}^{-1}$ (Table 2). It implied that some samples contained higher concentrations of $\mathrm{Ca}$ as compared to the BBS limit value, but all the samples were within the limit of WHO. Despite having some higher concentrations of $\mathrm{Ca}$ in some samples, the samples may not be threatening for human health. Generally, surface water does not contain a higher concentration of $\mathrm{Ca}$, but some groundwater samples may contain as high as $294.0 \mathrm{mg} \mathrm{L}^{-1} \mathrm{Ca}$ in Chuadanga District of Bangladesh (Nahar et al. 2014). Calcium concentrations in groundwater vary from 2.0 to $25.0 \mathrm{mg} \mathrm{L}^{-1}$ (Egbueri 2020). Also, an extremely low concentration of $\mathrm{Ca}$ was found in the groundwater of Bafia (Nyam et al. 2020). Calcium is the plentiful mineral in the human body, and this metal plays a vital role in cellular activities and in hormonal activities (Tandouan and Ulusu 2005).

Magnesium concentrations in the drinking water of the food stalls and restaurants varied from 19.44 to $51.04 \mathrm{mg}$ $\mathrm{L}^{-1}$ (Table 2). The BBS permissible limit of $\mathrm{Mg}$ is 30.0 to $35.0 \mathrm{mg} \mathrm{L}^{-1}$, and the WHO limit value is $150.0 \mathrm{mg} \mathrm{L}^{-1}$ (Table 2). It indicated that some samples surpassed the standard limit of BBS. But the obtained values were considered safe because the values were within the recommended value of WHO. The Mg concentration in the supplied drinking water in the restaurants of Sylhet city varies from 0.27 to $64.02 \mathrm{mg} \mathrm{L}^{-1}$ (Alam et al. 2006). The mean concentration of $\mathrm{Mg}$ in shallow tube well of South Central Coastal region was reported as $155.0 \mathrm{mg} \mathrm{L}^{-1}$ (Islam et al. 2017a). The $\mathrm{Mg}$ is a vital nutrient for human as well as other animals and it is the second most abundant mineral in the human body (Vallee et al. 1960).

\section{Iron (Fe)}

The iron concentration of the samples varied from 0.46 to $1.42 \mathrm{mg} \mathrm{L}^{-1}$ (Table 2). The BBS recommended value of $\mathrm{Fe}$ in drinking water is 0.30 to $1.00 \mathrm{mg} \mathrm{L}^{-1}$, and the WHO recommended limit value is $0.30 \mathrm{mg} \mathrm{L}^{-1}$ (Table 2). Considering
WHO guidelines, all the samples of the study area were not suitable for drinking purposes. If we consider the BBS standard, 16 out of 35 samples exceeded the Bangladesh standard limit and most of them were about to exceed the upper limit. The result suggested that about $45.71 \%$ of samples exceeded the BBS standard limit and the maximum concentration of $\mathrm{Fe}$ was $1.42 \mathrm{mg} \mathrm{L}^{-1}$ in NR at Chanchra (NR 6; Table-2). About $25 \%$ of restaurants of Sylhet city had unsafe and dubious levels of Fe (Alam et al. 2006). Nearly 26\% of groundwater samples of Dhaka city exceeded the limit value of WHO where the average concentration of Fe was about $0.21 \mathrm{mg} \mathrm{L}^{-1}$ (Bodrud-Doza et al. 2020). More than $60 \%$ of groundwater samples exceeded the WHO limit value (Nyam et al. 2020). On the contrary, very low concentration of $\mathrm{Fe}\left(0.04\right.$ to $\left.0.97 \mathrm{mg} \mathrm{L}^{-1}\right)$ was found in groundwater near a landfill site of Mongla Bazar, Sylhet (Alam et al. 2020). Iron concentration in supplied water varied from 0.12 to $6.21 \mathrm{mg}$ $\mathrm{L}^{-1}$ in Jashore Municipality (Shaibur et al. 2012). A high concentration of $\mathrm{Fe}$ in drinking water creates an unpleasant metallic taste. Iron plays a key role in human nutrition but high concentration in drinking water may create chronic anemia and fatigues (Søgaard et al. 2017).

\section{Total coliform and fecal coliform}

The maximum contamination of fecal coliform was 88.0 CFU/100 mL in SSFS at Kapuria Patti (SSFS 2) and the minimum was $8.0 \mathrm{CFU} / 100 \mathrm{~mL}$ in WFR at Palbari (WFR 4; Fig. 3). This was because the environmental condition of the SSFS in Kapuria Patti was worse. The other probable causes might be unhygienic behaviors of the people involved, unskilled manpower, unplanned distribution system, etc. Usually, they brought water in SSFS from the nearby tube wells or supplied water in an old and dirty container. From there, they transferred the water into a reused old and dirty plastic container of Coca-Cola, Pepsi or 7up. This might also be due to the fact that the sources of water itself contained a high concentration of coliform bacteria or bacterial contamination might occur during shipment and preservation in the plastic container. On the contrary,
Fig. 3 Concentration of Fecal Coliform (FC) and Total Coliform (TC) in different sources of food stalls. NR = Normal Restaurants, $\mathrm{TS}=$ Tea Stalls, SSFS $=$ Street Side Fast Food Stalls and WFR = Well-furnished Restaurants. Bars with different letters are significantly different $(p<0.05)$ according to a Ryan-Einot-Gabriel-Welsch multiple range test

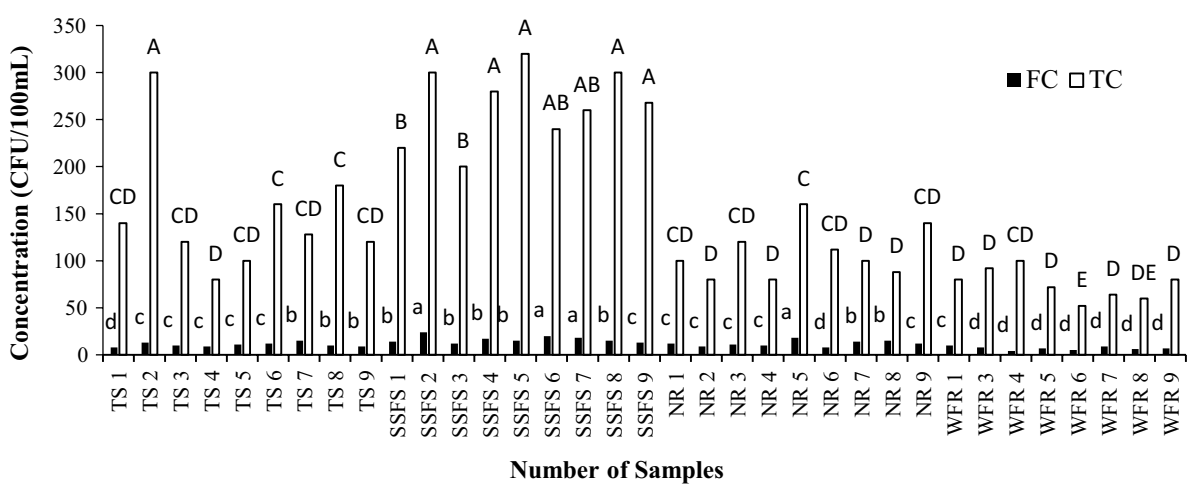

Number of Samples 
the environmental condition of WFR in Palbari was comparatively favorable. They (WFRs) serve the water directly to the consumer from the tube wells, though the tube well water itself contained coliform bacteria (Shaibur et al. 2012). Similar to the fecal coliform bacteria, the maximum total coliform was $320.0 \mathrm{CFU} / 100 \mathrm{~mL}$ also found in SSFS at Doratana (SSFS 5) and the minimum contamination was 60.0 CFU/100 mL in Chachra (WFR 6). The result demonstrated that the provided drinking water in SSFS was highly contaminated with fecal coliform as compared to the other types of food stalls in Jashore city.

A report showed that the water samples of all the popular restaurants in Sylhet city were contaminated by fecal coliform. There was also a great chance of contamination by many other pathogenic bacteria. It was also found that most of the water samples were significantly contaminated by TVC bacteria (Sarker et al. 2016) and with fecal coliform (Faruque et al. 2010). The water samples of restaurants of Chittagong contained fecal coliforms together with other bacteria (Nawas et al. 2012). It was reported that shallow tube wells of Shinduria village (Savar, Dhaka) contained 0.00 to $3.49 \times 10^{3} \mathrm{CFU} / 100 \mathrm{~mL}$ fecal coliforms and from $1.5 \times 10^{1}$ to $4.98 \times 10^{4} \mathrm{CFU} / 100 \mathrm{~mL}$ total coliform (Rahman et al. 2013). A recent study also revealed that about $81.2 \%$ water samples of tube well water of different Districts in Bangladesh are contaminated with coliforms (Parvez et al. 2016). Most of the groundwater samples (10 to $45 \mathrm{~m}$ ) of Rajshahi city contained preeminent content of TC. Some samples exceeded the FC content recommended by WHO and BBS (Mostafa et al. 2017).

Generally, the water of deep tube well is free from disease producing microorganisms (Shaibur et al. 2012) which are normally present in adequate numbers in surface water. Present findings showed that the provided water in different food stalls was contaminated by a high concentration of harmful fecal coliform bacteria. This high concentration of coliform bacteria might be responsible for the diarrhea, dysentery or gastric problem of the people in the Jashore Municipal area. The result confirmed that the water used in different food stalls in Jashore city was not suitable for drinking purpose. This is the core findings of this research. It was suggested that such types of provided water must not be used in food stalls for drinking purposes because the water is biologically unsuitable. It might cause different levels of health risk and the supplied water in the food stall is a threat to human health.

\section{Conclusions and recommendations}

The microbial quality of drinking water was one of the major concerns considering the health effect on consumers. The study revealed that most of the physicochemical parameters of the sampled water were within the permissible level of BBS and WHO drinking water quality guidelines. The Ca and $\mathrm{Mg}$ concentrations were in threatening position, while the Fe concentrations in all the samples imposed substantial risk. Furthermore, despite having almost the desirable conditions of the maximum parameters, the presence of high concentrations of fecal coliform made the provided water unsuitable for drinking purposes. The water provided in the present system in the different food stalls in Jashore city should be stopped immediately. The microbial contaminations in WFR were comparatively lower than the other three categories. The water of SSFF, TS and NR was highly contaminated by fecal coliform. Considering all measured parameters, it could be concluded that the provided water in different food stalls and restaurants of Jashore Municipality failed to meet up the potable drinking water quality standards.

It is recommended that the original sources of water need to be improved first. Then, the collection and storage system should also be improved. It is strongly recommended that the storage tanks or containers need to be cleaned up frequently with disinfectants. Awareness of the concerned people must be increased abruptly and they must have the concept of food security and hygiene. The awareness of water hygiene behaviors could help maintain cleanliness in a more hygienic condition of these food stalls and restaurants. In another way, water should be collected from the scientific storage tank or container through the clean tap or container having a long handle and should be served to the customer without dipping the hands in the storage tanks. Continuous surveillance facilities should be in place for the distribution system to ensure the supply of safe drinking water for these food stalls and restaurants of the Municipality. Lastly, the heavy metals and metalloid also need to be determined in knowing the actual condition of water quality.

Acknowledgements We are very much grateful to the owners of food stalls who kindly helped us to provide the necessary data. We are grateful to Mr. Ishtiaque Ahmmed for the analysis of the data.

Funding This research was conducted with self-funding.

\section{Declarations}

Conflict of interest There is no conflict of interest regarding this manuscript.

Open Access This article is licensed under a Creative Commons Attribution 4.0 International License, which permits use, sharing, adaptation, distribution and reproduction in any medium or format, as long as you give appropriate credit to the original author(s) and the source, provide a link to the Creative Commons licence, and indicate if changes were made. The images or other third party material in this article are included in the article's Creative Commons licence, unless indicated otherwise in a credit line to the material. If material is not included in the article's Creative Commons licence and your intended use is not 
permitted by statutory regulation or exceeds the permitted use, you will need to obtain permission directly from the copyright holder. To view a copy of this licence, visit http://creativecommons.org/licenses/by/4.0/.

\section{References}

Adimalla N, Taloor AK (2020) Hydrogeochemical investigation of groundwater quality in the hard rock terrain of South India using Geographic Information System (GIS) and groundwater quality index (GWQI) techniques. Groundw Sustain Dev 10(2020):100288. https://doi.org/10.1016/j.gsd.2019.100288

Alam R, Alam JB, Hasan MM, Das SR, Rahman K, Banik BK (2006) Study of water quality of Sylhet city and its restaurants: health associated risk assessment. Iran J Environ Health Sci Eng 3(1):9-18

Alam R, Ahmed Z, Howladar MF (2020) Evaluation of heavy metal contamination in water, soil and plant around the open landfill site Mogla Bazar in Sylhet. Bangladesh Groundw Sustain Dev 10(2020):100311. https://doi.org/10.1016/j.gsd.2019.100311

Ashbolt NJ (2004) Microbial contamination of drinking water and disease outcomes in developing regions. Toxicol 198:229-328

BBS (2009) Bangladesh Bureau of Statistics. Planning Division, Ministry of Planning, Government of the People's Republic of Bangladesh. Bangladesh National Drinking Water Quality Survey 2009

Bodrud-Doza M, Islam SMDU, Rume T, Shamshad B, Quraishi SB, Rahman MS, Bhuiyan MAH (2020) Groundwater quality and human health risk assessment for safe and sustainable water supply of Dhaka City dwellers in Bangladesh. Groundw Sustain Dev 10(2020):100374. https://doi.org/10.1016/j.gsd.2020.100374

da Silva MEZ, Santana RG, Guilhermetti M, Filho IC, Endo EH, Nakamura TU, Nakamura CV, Filho BPD (2008) Comparison of the bacteriological quality of tap water and bottled mineral water. Int J Hy Environ Health. 211:504-509

Das TK, Rani K, Mamun AM, Howlader M, Shaibur MR (2021a) Determination and distribution of groundwater composition in deep aquifer of Satkhira Municipality. Polish J Environ Stud, Bangladesh. https://doi.org/10.15244/pjoes/132635(accepted)

Das TK, Shaibur MR, Rahman MM (2021b) Groundwater chemistry at deep aquifer in coastal koyra upazila under Khulna District of Bangladesh. Current World Environ 16(2)

Diersing N (2009) Phytoplankton blooms: the basics. Florida Keys National Marine Sanctuary, Key West, Florida, USA, Available at: http://floridakeys.noaa.gov/pdfs/wqpb.pdf on 11 April, 2020

Eaton AD, Slesceri LS, Rice EW, Greenberg AE (2005) Standard methods for the examination of water and waste water, 21st Edn. Centennial Edition, Geneva, Switzerland

Egbueri JC (2020) Groundwater quality assessment using pollution index of groundwater (PIG), ecological risk index (ERI) and hierarchical cluster analysis (HCA): a case study. Groundw Sustain Dev. 10(2020):100292. https://doi.org/10.1016/j.gsd.2019.100292

Faruque Q, Haque QF, Shekhar HU, Begum S (2010) Institutionalization of healthy street food system in Bangladesh: a pilot study with three wards of Dhaka City Corporation as a model, Final Report PR \#7/07ByQu

Hasan MK, Shahriar A, Jim KU (2019) Water pollution in Bangladesh and its impact on public health. Heliyon 5(8):e02145

Huang PM, Fujii R (2001) Selenium and arsenic. In: Sparks DL (ed) Methods of soil analysis, part 3-chemical methods, SSSA book series 5. Soil Science Society of America and American Society of Agronomy, Madison, pp 793-831

Islam MS, Haque ME, Nigar S, Hasan SMA, Shaibur MR (2015) Nutritional status of government primary school children at urban areas of Jashore district in Bangladesh. J InnovDevelop Strat 9(2):28-33
Islam MA, Zahid A, Rahman MM, Rahman MS, Islam MJ, Akter Y (2017a) Investigation of groundwater quality and its suitability for drinking and agricultural use in the south central part of the coastal region in Bangladesh. Expo Health 9(1):27-41

Islam N, Arefin MS, Nigar T, Haque SN, Haq KI, Emran MTA, Nazrul $\mathrm{T}$ (2017b) Street food eating habits in Bangladesh: a study on Dhaka City. Int J Manage Develop Stud 6(9):49-57

Islam SMDU, Bhuiyan MAH, Rume T, Azam G (2017c) Hydrogeochemical investigation of groundwater in shallow coastal aquifer of Khulna District, Bangladesh. Appl Water Sci 7:4219-4236. https://doi.org/10.1007/s13201-017-0533-5

Kelly WR, Panno SV, Hackley K (2012) Illinois state water survey. Prairie Research Institute, University of Illinois at Urbana-Champaign, Champaign, Illinois. The Sources, Distribution, and Trends

Khairuzzaman M, Chowdhury FM, Zaman S, Mamun AA, Bari ML (2014) Food safety challenges towards safe, healthy, and nutritious street foods in Bangladesh. Int J Food Sci 2014:483519. https:// doi.org/10.1155/2014/483519

Lahlou ZM (2002) Water quality in distribution systems. A national drinking water clearinghouse fact sheet, West Virginia University, Tech Brief

Mahmud A, Sikder S, Joardar JC (2020) Assessment of groundwater quality in Khulna city of Bangladesh in terms of water quality index for drinking purpose. Appl Water Sci 10:226. https://doi. org/10.1007/s13201-020-01314-z

Mostafa MG, Uddin SMH (2017) Haque ABMH (2017) Assessment of hydro-geochemistry and groundwater quality of Rajshahi City in Bangladesh. Appl Water Sci 7:4663-4671. https://doi.org/10. 1007/s13201-017-0629-y

Nabi MS (2018) World Bank: 41\% of the country's 'improved' water sources laced with E. coli Dhaka Tribune, 12 October, 2018

Nahar MS, Zhang J, Ueda A, Yoshihisa F (2014) Investigation of severe water problem in urban areas of a developing country: the case of Dhaka. Bangladesh Environ Geochem Health 36(6):1079-1094

Nawas T, Mazumdar RM, Das S, Nipa MN, Islam S, Bhuiyan HR, Ahmad I (2012) Microbiological quality and antibiogram of E. coli, salmonella and vibrio of salad and water from restaurants of Chittagong. J Environ Sci Nat Resour 5(1):159-166

Nyam FMEA, Yomba AE, Tchikangoua AN, Bounoung CP, Nouayou $R$ (2020) Assessment and characterization of groundwater quality under domestic distribution using hydrochemical and multivariate statistical methods in Bafia. Cameroon Groundw Sustain Dev 10(2020):100347. https://doi.org/10.1016/j.gsd.2020.100347

Parvez AK, Liza SM, Marzan M, Ahmed A, Rahman MH (2016) Bacteriological quality of drinking water samples across Bangladesh. Arch Clin Microbiol 7(1):9

Rahman SH, Fakhruddin ANM, Uddin MJ, Zaman MS, Talukder A, Adyel TM, Sarker MMR (2013) Water quality of shallow tube wells as affected by sanitary latrines and groundwater flow. $\mathbf{J}$ Bangladesh Acad Sci 37(2):231-243

Rahman MM, Islam MA, Bodrud-Doza M, Muhib MI, Zahid A, Shammi M, Tareq SM, Kurasaki M (2017) Spatio-temporal assessment of groundwater quality and human health risk: A case study in Gopalganj. Expo Health, Bangladesh. https://doi.org/10. 1007/s12403-017-0253-y

Sardar S, Uddin MN, Reza MS, Jamil AHMN (2017) Evaluation of drinking water quality in Jessore district. Bangladesh IOSR J Biotech Biochem 3(4):59-62

Sarker A, Dash S, Hoque MM, Ahmed S, Shaheb MR (2016) Assessment of microbial quality of water in popular restaurants in Sylhet City of Bangladesh. Bangladesh J Agric Res 41(1):115-125

SAS (1988) SAS/STAT User's guide, No. 1, ANOVA, Version6.4th edn. Statistical Analysis System Institute, Cary

Sekar DM, Thamilselvi MR (2016) Factors influencing consumers to prefer the street vended foods. Asia Pacific J Res ISSN (Print): $2320-5504$

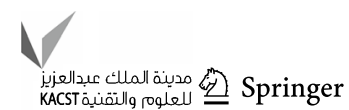


Semenza J, Roberts L, Henderson A, Boean J, Rubin C (1998) Water distribution system and diarrheal disease transmission: case study in Uzbekistan. Anterican J Trop Med Hygi 59(6):941-946

Shaibur MR (2019) Distribution of arsenic and heavy metals and correlation among them in groundwater of South Fukra, Kashiani, Gopalganj. Bangladesh Environ Biol Res 1(1):84-105

Shaibur MR, Ahmmed I, Rumpa SS, Parvin S, Hossain MS, Rahman MM, Sarwar S (2019a) Physico-chemical parameters of groundwater at Jashore University of Science and Technology campus and its surrounding villages. J Jess Univ Sci Tech 4(1):34-45

Shaibur MR, Anzum HMN, Rana MS, Khan MAS (2012) Assessment of supplied water quality at Jessore Municipality (Pourashava), Bangladesh. Bangladesh J Environ Res 10:69-87

Shaibur MR, Anzum HMN, Rana MS, Sarwar S (2019b) Water supply and sanitation status in Jashore Municipality. Bangladesh Environ Biolog Res 1(1):12-21

Shaibur MR, Habiba U, Ritu SN, Sharkar MA, Das RR (2019c) Effectiveness of tea residue, orange peel and charcoal to minimize the pollution caused by tannery industry in Jashore. Bangladesh J Jess Univ Sci Tech 4(1):1-10

Shaibur MR, Hossain MS, Sony SJ (2019d) Drinking water quality of hand tube well water at sub-urban areas of Jashore Municipality. Bangladesh J Jess Univ Sci Tech 4(1):11-22

Shaibur MR, Howlader M (2020) Groundwater composition at some unions in Kashiani and Kotalipara upazila of south-central coastal Gopalganj district. Bangladesh Environ Biol Res 2(2):22-36

Shaibur MR, Husain H, Arpon SH (2021a) Utilization of cow dung residues of biogas plant for sustainable development of a rural community. Curr Res Environ Sustain 3:100026. https://doi.org/ 10.1016/j.crsust.2021.100026

Shaibur MR, Nahar N, Rahman MH (2018) Probable relationship between climate change and cropping pattern in Jashore District. J Jess Univ Sci Tech 3(1):7-13

Shaibur MR, Parvin S, Ahmmed I, Rahaman MH, Das TK, Sarwar S (2021b) Gradients of salinity in water sources of Batiaghata, Dacope and Koyra upazila of coastal Khulna district. Bangladesh Environ Chall 4(2021):100152. https://doi.org/10.1016/j.envc. 2021.100152

Shaibur MR, Rizvi MM, Islam MK, Shamsunnahar (2019f) Salinity causes ecosystem disruption and biodiversity losses in Beel Khuksia: Keshabpur, Jashore, Bangladesh. Environ Biolog Res 1(1):1-11
Shaibur MR, Shamim AHM, Khan MH (2019e) Water quality of different sources at Buri Goalini and Gabura Unions of Shyamnagar Upazila, Bangladesh. Environ Biolog Res 1(1):32-43

Shaibur MR, Tanzia FKS, Karim MM, Rahman MH (2017) Aspects of Bangladesh water development board on the ecosystems and water quality of Nolamara beel in Narail District of Bangladesh. Bangladesh J Environ Sci 32:144-151

Søgaard KL, Ellervik C, Svensson J, Thorsen SU (2017) The role of iron in type 1 diabetes etiology: a systematic review of new evidence on a long-standing mystery. Rev Diabat Stud 14:269-278

Sultana MS, Islam MS, Saha R, Al-Mansur M (2009) Impact of the effluents of textile dyeing industries on the surface water quality inside DND embankment Narayanganj Bangladesh. J Sci Ind Res 44(1):65-80

Tambekarv DH, Hirulkarv NB, Bhokrev DD, Gulhanev SR, Banginwarv YS (2006) Studies of hygiene behavior on bacteriological quality deterioration of water in hotels and restaurants. Res J Microbiol 1:183-189

Tandouan B, Ulusu NN (2005) Importance of calcium. Turk J Med Sci 35:197-201

USEPA (2014) USEPA Integrated Risk Information System (IRIS) online database

Vallee BL, Wacker WE, Ulmer DD (1960) The magnesium-deficiency tetany syndrome in man. Boston Med Surg J 262(4):155-161

Whelton AJ, Dietrich AM, Burlingame GA, Schechs M, Duncan SE (2007) Minerals in drinking water: impacts on taste and importance to consumer health. Water Sci Tech 55(5):283-291

WHO (1984) Guideline for drinking water quality. 20 Avenue, Appia, 1211, Geneva 27, Switzerland

WHO (2004) Guidelines for drinking-water quality. Volume 1, Recommendations, $3^{\text {rd }}$ edition.20 Avenue, Appia, 1211, Geneva 27, Switzerland

WHO (2011) Guidelines for drinking-water quality. Fourth edn.20 Avenue, Appia, 1211, Geneva 27, Switzerland

WHO (2017) Geneva. UN-water global analysis and assessment of sanitation and drinking-water (GLAAS), 2017 Report: Financing universal water, sanitation and hygiene under the Sustainable. 20 Avenue, Appia, 1211, Geneva 27, Switzerland

Publisher's Note Springer Nature remains neutral with regard to jurisdictional claims in published maps and institutional affiliations. 